\title{
The effects of salt stress and prime on germination improvement and seedling growth of Calotropis procera L. seeds
}

\author{
Mansour Taghvaei*, Nazila Khaef and Hossein Sadeghi \\ Department of Desert Region Management, College of Agriculture, Shiraz University, Shiraz P. O. Box 71441-65186, Iran
}

\begin{abstract}
Calotropis procera L. is a perennial shrub distributed in saline areas of deserts of South Asia. Salt stress is a very challenging subject in arid and semi-arid areas. Germination stage is very sensitive and many plants do not germinate in saline soil. The objective of this study was identifying the salinity effect on seed germination of Calotropis procera L. The experimental design was a complete randomized block design with $\mathrm{NaCl}$ and $\mathrm{CaCl}_{2}$ at five levels of isobar concentrations: $0.0,-0.01,-0.05,-0.1$, and $-0.15 \mathrm{MPa}$. Osmotic potential had significant effects $(P<0.01)$ on germination percentage, germination rate, shoot length, root length, and seedling dry weight. All seedling characteristics decreased with decrease in osmotic potential. Shoot length and root length decreased more than the seedling characteristics. Germination was completely inhibited in -0.1 Mpa. Priming with $\mathrm{NaCl}$ and $\mathrm{CaCl}_{2}(-0.1 \mathrm{MPa})$ for four days had significant effects $(P<0.01)$ on the germination percentages. Priming improved the seedling characteristics in all samples, especially in -0.05 Mpa, but a decrease with decrease in osmotic potential.
\end{abstract}

Key words: Calotropis procera L., prime, salinity, seed germination

\section{INTRODUCTION}

Calotropis procera L. (Asclepiadaceae) is a perennial shrub found in many areas of the Asian deserts (Gutterman 1995). In these areas the average annual rainfall is between 30 and $200 \mathrm{~mm}$, or less (Fu 1989). Calotropis sp. is distributed in Asia from the Mediterranean to the Africa coast. In Iran it is mainly distributed in the Fars province (Lamerd) and can be found in the Zahedan province as well. Iran is a country in the mid-latitude belt of arid and semi-arid regions of the Earth. Approximately $60 \%$ of Iran is classified as arid and semi-arid (Milton 1995). The main role of this species is in restoration of degraded lands and sustenance of these areas. In arid and semi arid lands, evaporation increases and rainfall is almost nonexistent during summer. As a consequence, the salt concentration in topsoil increases (Lin and Chen 1995). Calotropis sp. regenerate by seed. Calotropis sp. produces lots of small seeds that dispread by wind. Establishment of the species in a new site depends on seed dispersal, germination, and establishment of seedlings. Seed germination is extremely sensitive to soil salinity. Salinity stress reduces the percentage of germination and delays the initiation of the germination process (Baskin and Baskin 1997). Seeds of most halophytes germinate in non-saline conditions (Ungar 1995). Therefore, in saline conditions germination occurs after precipitation, where topsoil salinity is usually reduced (Heydecker et al. 1973). Ghaedi et al. (2010) reported that seeds of Haloxylon aphyllum L. as a halophyte is sensitive to salinity. Therefore, distribution of halophytes in saline environment depends on their germination tolerance to salinity. Jhala (1997) recognized that

\section{Open Access http://dx.doi.org/10.5141/JEFB.2012.011}

This is an Open Access article distributed under the terms of the Creative Commons Attribution Non-Commercial License (http://creativecommons. org/licenses/by-nc/3.0/) which permits unrestricted non-commercial use distribution, and reproduction in any medium, provided the original work is properly cited.
Received 17 December 2011, Accepted 02 March 2012

*Corresponding Author

E-mail: taghvaei@shirazu.ac.ir Tel: +98-711-613-8163 
there is a relation between salt tolerances at germination and the tolerance level during seedlings growth. There is little information available on the germination response on Calotropis procera L. seeds. Priming with a salinity stress had specific effects on different species (Gutterman 1997, Alimentacion et al. 2006, Khaef et al. 2011). In some species, seeds germinate when they are transferred from $\mathrm{NaCl}$ to distilled water (Khan and Rizvi 1994). In some halophyte like seeds of Medicago ruthenica and Salsola vermiculata, germination starts in distilled water after pretreatment under a saline or osmotic concentration (Alimentacion et al. 2006, Guan et al. 2009, Ghaedi et al. 2009). Calotropis sp. is an important economic plant used for drug and other purposes. Scientists wanted to understand its biological and ecological germination characteristics. Calotropis sp. regenerate by seeds and produce many seeds, but its density is very low in salty lands. It seems that germination of Calotropis sp. seeds is sensitive to salinity in the arid regions and occurs after rainfall when the soil salinity is reduced (Gulzar and Khan 2001). This study was conducted to investigate the effects of salinity on germination, seedling growth, and after priming of Calotropis procera L. seeds.

\section{MATERIALS AND METHODS}

Mature seeds of Calotropis procera L. were collected from the shrubs of natural populations in the desert area in Fars province (Lamerd, $28^{\circ} \mathrm{N}$ and $53^{\circ} \mathrm{E}$ altitude) in 2010. The monthly precipitation and mean monthly temperatures are shown in Table 1. Seeds were hand separated from the pods and stored in a refrigerator at a temperature of $5^{\circ} \mathrm{C}$. The experimental design was a complete randomized block design with five levels of $\mathrm{NaCl}$ and $\mathrm{CaCl}_{2}$ iso- bar concentrations: $0.0,-0.01,-0.05,-0.1$, and $-0.15 \mathrm{MPa}$. Experiments were carried out with four replicates of 50 seeds each, on Whatman No. 1 filter paper, in $90 \mathrm{~mm}$ diameter Petri dishes at $30^{\circ} \mathrm{C}$. Seed germination was carried out under visible light of 400-700 $\mathrm{nm}$ wavelength. The seeds were considered to have been germinated when the lengths of the emerging radicals were over $2 \mathrm{~mm}$ (International Seed Testing Association 1999). Germinated seedlings were counted every day, for 15 days.

\section{Recovery}

Calotropis procera $\mathrm{L}$. seeds were treated with $\mathrm{NaCl}$ and $\mathrm{CaCl}_{2}(-0.1 \mathrm{MPa})$ at $30^{\circ} \mathrm{C}$ for 4 days. The treated seeds were then transferred to levels of salinity $\left(\mathrm{NaCl} / \mathrm{CaCl}_{2}\right.$ ratio) potentials $0.0,-0.01,-0.05,-0.1$, and $-0.15 \mathrm{MPa}$. At the end of the experiment, the number of germinated seeds were observed and the percentage of germination was calculated. Mean time to full germination (MTG) was calculated according to the Eliss and Roberts equation (1981). The germination rate was calculated by inverse of MTG (Tobe et al. 2000) as follows:

$$
\begin{aligned}
& \text { MTG }=\sum(\text { ni.ti }) / \sum n \\
& \text { GR }=1 / \text { MTG }
\end{aligned}
$$

MTG: Mean time to full germination

GR: germination rate

$n$ : number of seeds newly germinating at time ' $t$ '

ti: number of day from sowing.

Seedling dry weights were measured after drying for 24 $\mathrm{h}$ in an oven at $70^{\circ} \mathrm{C}$ (International Seed Testing Association 1999).

\begin{tabular}{|c|c|c|c|c|c|c|c|c|c|c|c|c|c|}
\hline & Jan & Feb & Mar & Apr & May & Jun & Jul & Aug & Sep & Oct & Nov & Dec & Annual \\
\hline $\begin{array}{l}\text { Maximum } \\
\text { temperature } \\
\left({ }^{\circ} \mathrm{C}\right)\end{array}$ & 21.5 & 28.5 & 28.5 & 31.4 & 39 & 44.3 & 45.3 & 44.1 & 42.2 & 38.5 & 31.5 & 24.5 & 34.9 \\
\hline $\begin{array}{l}\text { Minimum } \\
\text { temperature } \\
\left({ }^{\circ} \mathrm{C}\right)\end{array}$ & 6.5 & 8.5 & 15.5 & 15.7 & 20.5 & 24.2 & 25.5 & 26 & 23.5 & 18.2 & 13.3 & 7.5 & 17.1 \\
\hline $\begin{array}{l}\text { Mean } \\
\text { temperature } \\
\left({ }^{\circ} \mathrm{C}\right)\end{array}$ & 14 & 17.5 & 17 & 23.5 & 34.2 & 34.2 & 35.5 & 35 & 33.2 & 24.4 & 22.4 & 16 & 25.6 \\
\hline $\begin{array}{l}\text { Precipitation } \\
(\mathrm{mm})\end{array}$ & 63.6 & 43.5 & 10.8 & 24.4 & 0.5 & 0.15 & 0 & 0.25 & 0 & 0.6 & 11.5 & 99.2 & 254.5 \\
\hline
\end{tabular}

Table 1. Average of the maximum and minimum temperatures and the monthly average of the total precipitation of the desert area in Fars province 


\section{Data analyses}

Data were analyzed using 'MSTATC' statistical software (MStatC Inc., East Lansing, MI, USA). Means were separated by Duncan test in cases in which the $F$-value of the treatments was significant at the $P<0.05$ or $P<0.01$ Probability levels.

\section{RESULTS}

\section{Germination percentage}

Salinity had significant effects on germination percentages (Table 2). The highest germination percentage was found in distilled water. The lowest germination percentage was found in -0.05 MPa. Percentages of seed germination at -0.01 MPa and -0.05 MPa were significantly different (Table 3). Priming by $\mathrm{NaCl}$ and $\mathrm{CaCl}_{2}$ had significant effects on germination percentages (Table 3). For example over all final germination percentages were comparable in both non-primed and primed seeds in the case of control and treatment with -0.1 MPa, but germination percentage in primed seed with $\mathrm{NaCl}$ and $\mathrm{CaCl}_{2}$ were significantly higher than non-primed seeds. Germination occurred in -0.15 MPa in primed seeds with $\mathrm{NaCl}$, but no germination was found in non-primed seeds (Table 3). Germination occurred in -0.15 $\mathrm{MPa}$ of $\mathrm{CaCl}_{2}$ prime (Table 3).

\section{Germination rate}

Germination rate was significantly affected by salinity (Table 2). Mean value showed that the highest germination rate was found in distilled water $(0.0 \mathrm{MPa})$. The lowest germination rate was found in -0.05 MP. Germination rate at -0.01 and $0.0 \mathrm{MPa}$ was significantly different (Table 2). Priming significantly improved the germination rate (Table 3 ). The average germination rate in con- trol for non-primed seeds with $\mathrm{NaCl}$ and $\mathrm{CaCl}_{2}$ was 0.33 (seed/h), while that of the primed seeds were 0.37 and 0.35 (seed/h), respectively. The germination rate of the primed seeds was significantly higher at over all levels of osmotic potentials of $\mathrm{NaCl}$ and $\mathrm{CaCl}_{2}$ than in non-primed seeds (Table 3 ).

\section{Root length}

Salinity had significant effects on root length (Table 2). The mean showed that the highest root length was found in distilled water. Root length in the control was $1.5 \mathrm{~cm}$, but at $-0.05 \mathrm{Mpa}$, it was only 0.71 and 3.2, respectively (Table 3). The lowest root length was found in -0.01 and -0.15 $\mathrm{MPa}$ of $\mathrm{NaCl}$ and $\mathrm{CaCl}_{2}$ (Table 3). Priming by $\mathrm{NaCl}$ and $\mathrm{CaCl}_{2}$ had significant effects on root length (Table 2). The priming increased the root length in all levels of osmotic potential studied (Table 3 ).

\section{Shoot length}

Salinity had significant effects on shoot length (Table 2). The mean showed that the highest shoot length was found in distilled water. The lowest shoot length was found in 0.01 and $0.05 \mathrm{MPa}$. Shoot length at $0.01 \mathrm{MPa}$ and distilled water was significantly different (Table 3). Root length was significantly affected by priming with $\mathrm{NaCl}$ and $\mathrm{CaCl}_{2}$ in all levels of osmotic potential (Table 3). Root length in the control was $1.5 \mathrm{~cm}$, but after priming with $\mathrm{NaCl}$ and $\mathrm{CaCl}_{2}$ increased to 8.2 and $8.3 \mathrm{~cm}$, respectively, but decreased with decrease in osmotic potential (Table 2).

\section{Seedling dry weight}

Seedling dry weights were significantly affected by salinity (Table 2). The mean showed that the highest seedling dry weight was found in distilled water. The lowest

Table 2. Analysis at variance for seed and seedling parameters

\begin{tabular}{lcccccc}
\hline Source different & $\begin{array}{c}\text { Degrees of } \\
\text { freedom }\end{array}$ & $\begin{array}{c}\text { Germination } \\
(\mathbf{\%})\end{array}$ & $\begin{array}{c}\text { Germination } \\
\text { rate (G/day) }\end{array}$ & $\begin{array}{c}\text { Shoot length } \\
(\mathbf{c m})\end{array}$ & $\begin{array}{c}\text { Root length } \\
(\mathbf{c m})\end{array}$ & $\begin{array}{c}\text { Seedling } \\
\text { dry weight }\end{array}$ \\
\hline Replication & 3 & $1.23^{\mathrm{ns}}$ & $1.56^{\mathrm{ns}}$ & $0.65^{\mathrm{ns}}$ & $0.43^{\mathrm{ns}}$ & $1.67^{\mathrm{ns}}$ \\
Salinity (A) & 4 & $30.9^{* *}$ & $4.32^{* *}$ & $16.45^{* *}$ & $4.98^{* *}$ & $9.76^{* *}$ \\
Pretreatment (B) & 1 & $43.7^{* *}$ & $5.87^{* *}$ & $18.36^{* *}$ & $6.32^{*}$ & $11.21^{* *}$ \\
A*B & 4 & $7.93^{* *}$ & $1.94^{\mathrm{ns}}$ & $1.54^{\mathrm{ns}}$ & $1.23^{\text {ns }}$ & $5.11^{*}$ \\
Error & 27 & 8.9 & 0.005 & 1.118 & 0.026 & 0.00001
\end{tabular}

Significance at ${ }^{*} P<0.05,{ }^{* *} P<0.01 ;$ ns, no significance. 


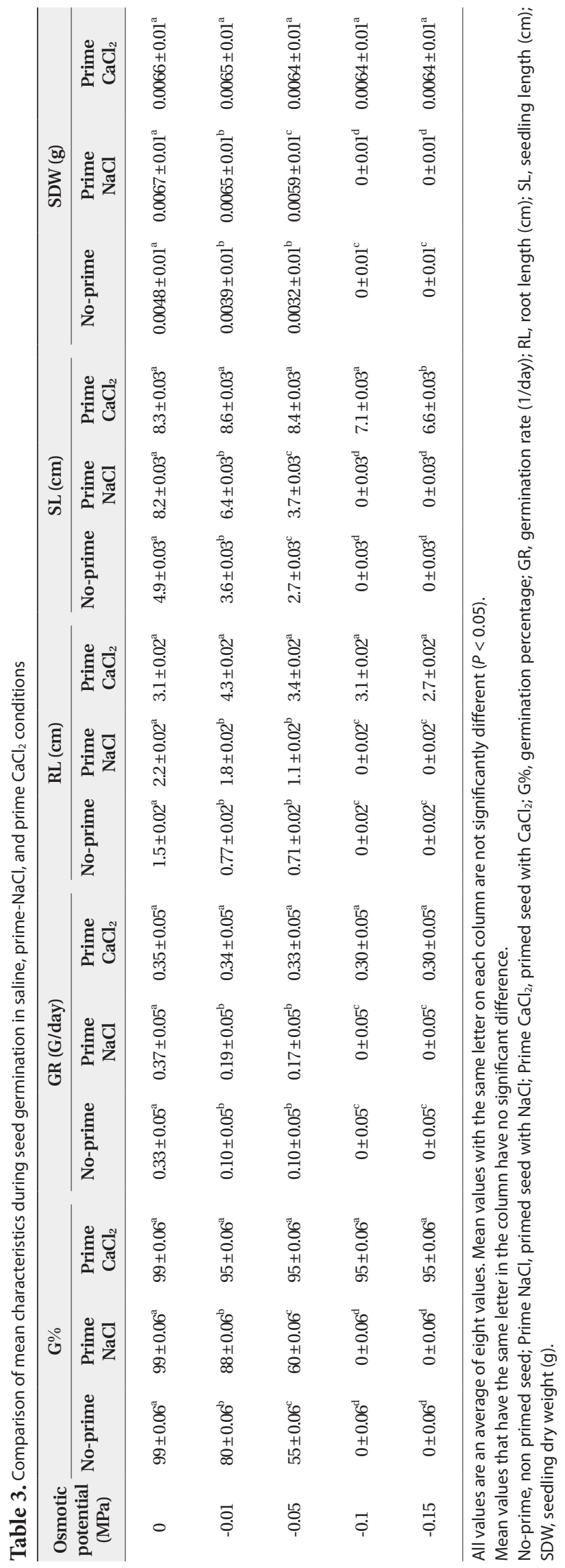

seedling dry weight was found in $0.05 \mathrm{MPa}$. Seedling dry weights at $0.01 \mathrm{MPa}$ and distilled water were significantly different (Table 2). Priming with $\mathrm{NaCl}$ had significant effects on seedling dry weight (Table 2). The priming increased the seedling dry weight significantly $(P<0.01)$ in all levels of osmotic potential studied. Priming with $\mathrm{NaCl}$ increased the seedling dry weight more than that with $\mathrm{CaCl}_{2}$. However, there was no significant difference (Table 2).

\section{DISCUSSION}

The results showed that Calotropis sp. is sensitive to salinity in germination stage. Several perennial halophytes were sensitive to higher salinities during the germination phase (De Villiers et al. 1994, Delesalle and Blum 1994, Khan and Ungar 1998, Gulzar et al. 2001, Khan et al. 2001, Aiazzi et al. 2002). Germination and other characteristics of Calotropis seedlings decreased with increasing salinity, and were substantially inhibited at -0.1 and $0.15 \mathrm{MPa}$ $\mathrm{NaCl}$. Maximum germination was obtained in the nonsaline and distilled water controls. Low osmotic potential decreases the water uptake of the seeds; thereby, inhibiting the germination (Dodd and Donovan 1999). Similar results were reported for Salsola vermiculata (Guma et al. 2010), Prosopis juliflora (El-Keblawy 2004), Medicago ruthenica (Guan et al. 2009), Haloxylon aphyllum (Ghaedi et al. 2009), and a number of annual halophytes (Ungar 1995). Osmopriming had significant effects on germination and characteristics of Calotropis sp. seedlings. Osmopriming improved germination percentage, germination rate, seedling length, and seedling dry weight of $C$. procera $\mathrm{L}$. seeds (Tables 2 and 3). Similar findings were reported in Atriplex sp. (Katembe et al. 1998). For plants, sodium ions $\left(\mathrm{Na}^{+}\right)$are harmful, whereas potassium ions $\left(\mathrm{K}^{+}\right)$are essential. Under the typical $\mathrm{NaCl}$-dominated salt environment in nature, accumulation of high $\mathrm{Na}^{+}$in the cytosol, and thus high $\mathrm{Na}^{+} / \mathrm{K}^{+}$ratios, disrupts the enzymatic functions in cells (Munns et al. 2006). Therefore, it is very important for cells to maintain a low concentration of cytosolic $\mathrm{Na}^{+}$or to maintain a low $\mathrm{Na}^{+} / \mathrm{K}^{+}$ratio in the cytosol when under $\mathrm{NaCl}$ stress due to the toxic effects of high concentrations of $\mathrm{Na}^{+}$(Maathuis and Amtmann 1999).

In general, the crops with the lowest $\mathrm{Na}^{+}$concentrations produced greater dry matter. This low- $\mathrm{Na}^{+}$genotype had fewer injured leaves, and a greater proportion of living to dead leaves (Munns and James 2003).

These results showed that in a natural environment, 
Calotropis seeds could remain in the soil of the field area when salinity levels were higher than their tolerance and after precipitation they normally grow (Ungar 1995). Experiments of prime germination identify that ion toxicity do not influence seeds of some halophytes (Salicornia europaea, Spergularia marina, Suaeda depressa, and Suaeda linearis), but osmotic effects reduce germination. Characteristics of $H$. recurvum were similar to that of Calotropis spin prime germination, since it is a halophyte and grows in the deserts of Pakistan (Khan and Ungar 1996). Priming is known as wetting under an osmotic potential or high salinity after seed washing. There are reports that priming permits early DNA replication (Bray et al. 1989), increased RNA and protein syntheses (Ibrahim et al. 1983), and results in greater ATP availability (Mazor et al. 1984). Seeds with applied preconditioning or priming have higher levels of germination rates and uniformity in comparison with non-primed seeds (Heydecker et al. 1973, Osborne et al. 1981).

\section{CONCLUSION}

Deserts are a region where humidity is scarce because the potential of evapotranspiration is higher than that of precipitation. In certain areas of these regions, the water table is near the soil surface and due to the high rate of evaporation, salts accumulate on the soil surface (Khan and Ungar 1998). Finally, due to humidity, seedling roots begin to grow on the surface layer of the soil. Seedling survival depends on the rapid growth of roots and their ability to reach the moist layers of the soil. After precipitation the salinity of the soil is washed and reduced, and priming happens. Because of prime seeds that do not germinated in saline soil grow. Clotropis procera (Asclepiadaceae) is a perennial shrub that is not a halophyte. It can be concluded that this species may not be tolerant to extreme soil salinity during germination but is highly tolerant during storage in the soil. Recruitment from seeds would be facilitated whenever the window of opportunity is available. Establishment of the species in a new site depends on the germination rate and establishment of seedlings. Seed germination in the plant life cycle is a critical stage for survival, especially under arid and unpredictable environmental conditions like those of the Mediterranean ecosystems (Giménez-Benavides et al. 2005). It seems that low distribution of Calotropis procera $\mathrm{L}$. is sensitive to salinity at germination. But seeds of Calotropis procera L. are tolerant to salinity. Priming of Calotropis procera L. seeds increased tolerance to salinity, and increases the germination rate, root, and shoot lengths, number of leaves increases photosynthesis and seedling weight. This study provides some basic information related to the suitability of environmental conditions for better germination of Calotropis procera L. seeds, which may be helpful.

\section{LITERATURE CITED}

Aiazzi MT, Carpane PD, Di Rienzo JA, Argüello JA. 2002. Effects of salinity and temperature on the germination and early seedling growth of Atriplex cordobensis Gandoger et Stuckert (Chenopodiaceae). Seed Sci Technol 30: 329-338.

Alimentacion INTA, Perez A, Tambelini C. 2006. Effect of saline and water stress and early aging on the algarroba seed germination. Pesq Agropecu Bras 30: 1289-1295.

Baskin CC, Baskin JM. 1997. Seeds, Ecology, Biogeography and Evolution of Dormancy, and Germination. Academic Press, New Dehli.

Bray CM, Davison PA, Ashraf M, Taylor RM. 1989. Biochemical events during osmopriming of leek seed. Ann Appl Biol 102: 185-193.

De Villiers AJ, Van Rooyen MW, Theron GK, Van de Venter HA. 1994. Germination of three Namaqualand pioneer species, as influenced by salinity, temperature and light. Seed Sci Technol 22: 427-433.

Delesalle VA, Blum S. 1994. Variation in germination and survival among families of Sagittaria latifolia in response to salinity and temperature. Int J Plant Sci 155: 187-195.

Dodd GL, Donovan LA. 1999. Water potential and ionic effects on germination and seedling growth of two cold desert shrubs. Am J Bot 86: 1146-1153.

Eliss RH, Roberts EH. 1981. The quantification of ageing and survival in orthodox seeds. Seed Sci Technol 9: 373-409.

El-Keblawy A. 2004. Salinity effects on seed germination of the common desert Range grass, Panicum turgidum. Seed Sci Technol 32: 873-878.

Fu LG. 1989. The Rare and Endangered Plants in China. Shanghai Educational Press, Shanghai. (in Chinese)

Ghaedi M, Taghvaei M, Fallah Shamsi SR, Niazi A. 2009. The interactive effect of light, temperature and salinity on seed germination of Haloxylon aphyllum L. Rangeland 3(3): 465-478.

Giménez-Benavides L, Escudero A, Pérez-García F. 2005. Seed germination of high mountain Mediterranean species: altitudinal, interpopulation and interannual variability. Ecol Res 20: 433-444.

Guan B, Zhou D, Zhang H, Tian Y, Japhet W, Wang P. 2009. Germination responses of Medicago ruthenica seeds to 
salinity, alkalinity, and temperature. J Arid Environ 73: 135-138.

Gulzar S, Khan MA. 2001. Seed germination of a halophytic grass Aeluropus lagopoides. Ann Bot 87: 319-324.

Gulzar S, Khan MA, Ungar IA. 2001. Effect of salinity and temperature on the germination of Urochondra setulosa (Trin.) C. E. Hubbard. Seed Sci Technol 29: 21-29.

Guma IR, Padrón-Mederos MA, Santos-Guerra A, ReyesBetancort JA. 2010. Effect of temperature and salinity on germination of Salsola vermiculata L. (Chenopodiaceae) from Canary Islands. J Arid Environ 74: 708-711.

Gutterman Y. 1995. Seed Germination of Desert Plants. Adaptations of Desert Organisms. Springer, Berlin.

Gutterman Y. 1997. Survival Strategies of Annual Desert Plants. Adaptations of Desert Organisms. Springer, New York.

Heydecker W, Higgins J, Gulliver RL. 1973. Accelerated germination by osmotic seed treatment. Nature 246: 42-44.

Ibrahim AE, Roberts EH, Murdoch. AJ. 1983. Viability of lettuce seeds. II. Survival and oxygen uptake in osmotically controlled storage. J Exp Bot 34: 631-640.

International Seed Testing Association. 1999. International rules of seed testing. Seed Sci Technol 27(Supplement): 1-333.

Jhala YV. 1997. Seasonal effects on the nutritional ecology of blackbuck Antilope cervicapra. J Appl Ecol 34: 13481358.

Katembe WJ, Ungar IA, Mitchell JP. 1998. Effect of salinity on germination and seedling growth of two Atriplex species (Chenopodiaceae). Ann Bot 82: 167-175.

Khaef N, Taghvaei M, Sadeghei H, Niaza A. 2011. Effect of light and temperature on seed germination of Calotropis procera $\mathrm{L}$. Rangeland 5(1): 19-26.

Khan MA, Gul B, Weber DJ. 2001. Seed germination in relation to salinity and temperature in Sarcobatus vermiculatus. Biol Plant 45: 133-135.

Khan MA, Rizvi Y. 1994. Effect of salinity, temperature, and growth regulators on the germination and early seedling growth of Atriplex griffithii var. stocksii. Can J Bot 72:
475-479.

Khan MA, Ungar IA. 1996. Influence of salinity and temperature on the germination of Haloxylon recurvum Bunge ex. Boiss. Ann Bot 78: 547-551.

Khan MA, Ungar IA. 1998. Seed germination and dormancy of Polygonum aviculare L. as influenced by salinity, temperature, and gibberellic acid. Seed Sci Technol 26: 107-117.

Lin TP, Chen MH. 1995. Biochemical characteristics associated with the development of the desiccation-sensitive seeds of Machilus thunbergii Sieb. \& Zucc. Ann Bot 76: 381-387.

Maathuis FJM, Amtmann A. 1999. $\mathrm{K}^{+}$nutrition and $\mathrm{Na}^{+}$toxicity: the basis of cellular $\mathrm{K}^{+} / \mathrm{Na}^{+}$ratios. Ann Bot 84: 123133.

Mazor LEA, Perl M, Negbi M. 1984. Changes in some ATPdependent activities in seeds during treatment with polyethyleneglycol and during the redrying process. J Exp Bot 35: 1119-1127.

Milton SJ. 1995. Spatial and temporal patterns in the emergence and survival of seedlings in arid Karoo shrubland. J Appl Ecol 32: 145-156.

Munns R, James RA. 2003. Screening methods for salinity tolerance: a case study with tetraploid wheat. Plant Soil 253: 201-218.

Munns R, James RA, Läuchli A. 2006. Approaches to increasing the salt tolerance of wheat and other cereals. J Exp Bot 57: 1025-1043.

Osborne DJ, Sharon R, Ben-Ishai R. 1981. Studies on DNA integrity and DNA repair in germinating embryos of rye (Secale cereal). Isr J Bot 29: 259-272.

Tobe K, Li X, Omasa K. 2000. Seed germination and radicle growth of a halophyte, Kalidium caspicum (Chenopodiaceae). Ann Bot 85: 391-396.

Ungar IA. 1995. Seed germination and seed-bank ecology of halophytes. In: Seed Development and Germination (Kigel J, Galili G, eds). Marcel Dekker, New York, pp 599628. 